\title{
Chapter 1 \\ The Process Model of Student Feedback on Teaching (SFT): A Theoretical Framework and Introductory Remarks
}

\author{
Sebastian Röhl, Hannah Bijlsma, and Wolfram Rollett
}

\begin{abstract}
Student feedback on teaching in schools, conceptualized as information on student perceptions of teaching, is described by many scholars as an effective instrument for the developmental use of teachers and teaching. Beyond that, various studies show that the productive use of this method is a very complex process in which a variety of aspects must be considered. As an introduction to this volume, this chapter presents a model based on findings from different research areas of feedback and school research, called Process Model of Student Feedback on Teaching (SFT). This model follows the steps of the student feedback process, starting with student perceptions of teaching, which must be professionally collected or measured. Subsequently, the teacher perceives and interprets this feedback information, which is linked to cognitive and affective reactions and processes. This can lead to an enhancement of teachers' knowledge about their own teaching and to the initiation of improvement-oriented actions, finally resulting in improved teaching and development of the teachers' professional competence. Thereby, characteristics of the organization, the students, and classes as well as the teachers need to be considered. This model serves as a framework for the subsequent overview of the contributions in this volume.
\end{abstract}

Keywords Student feedback $\cdot$ Process model $\cdot$ Student perceptions of teaching quality $\cdot$ Teacher development

\footnotetext{
S. Röhl $(\bowtie) \cdot$ W. Rollett $(\bowtie)$

University of Education, Freiburg, Germany

e-mail: sebastian.roehl@ph-freiburg.de

W. Rollett

e-mail: wolfram.rollett@ph-freiburg.de

H. Bijlsma

Section of Teacher Professionalization, University of Twente, Enschede, the Netherlands

e-mail: h.j.e.bijlsma@utwente.nl
} 


\section{Student Feedback in Schools}

Student learning processes are influenced by many different factors, including student, home, school, peer, headteacher, and teacher effects (Hattie, 2009). In schools, teachers are considered to be the most malleable, within-school influence on student learning (Haertel, 2013; Nye et al., 2004), because the teacher determines the events in the classroom to a large extent. In order to be able to work and develop toward their full potential, it is important for teachers to receive information on the quality of their teaching. The teachers can gain some insight into this through the results of monitoring learning success and their own class observations. Such information proves to be particularly helpful when it comes from outside sources. This "information provided by an agent (...) regarding aspects of one's performance" (Hattie \& Timperley, 2007, p. 81) is typically labeled as feedback. If feedback on teaching is considered as valuable information about teachers' performance and used accordingly, it can have positive effects on the professional development of teachers, the quality of teaching and student learning (Garet et al., 2017). Therefore, ideally there would be enough time and available methods to provide teachers with constructive feedback about their teaching in order to improve the quality of their teaching, and, as a follow-up, to positively affect the learning processes of their students.

However, often little energy is invested in education on constructive feedback to teachers about the quality of their teaching (Frase \& Streshly, 1994; Voerman et al., 2012). At the same time, classroom observations by an external observer are quite common in many school systems (Darling-Hammond, 2013). Unfortunately, to obtain a truly reliable picture of teaching quality, it is necessary to rate lessons several times, and these observations should be made by several trained observers (Praetorius et al., 2014). This makes the use of classroom observations time-consuming and expensive. On the other hand, using teachers' self-assessments of their lessons might result in invalid data, because it is questionable whether teachers are able to judge their own lessons-as they see teaching only from their own perspective (Kruger \& Dunning, 1999; Visscher, 2017)—and such self-assessments can hardly be looked on as an "information provided by an agent".

Another way to provide teachers with feedback is to use student perceptions of teaching quality (Muijs, 2006; Peterson et al., 2000). If student perceptions are used, the number both of observed lessons (in cases where students access one teacher's teaching over several lessons) and of observers (the number of students) is larger than in the case of lesson observations by external persons, which could thus improve the reliability of the feedback scores (Fauth et al., 2014). In addition, student perceptions reflect the perspective of the target group (Kane \& Staiger, 2012; Quaglia \& Corso, 2014; Staiger, 2012).

Although there are concerns about the validity and reliability of student perceptions of teaching quality (e.g., the extent to which students are able to discriminate between the different facets of teaching: de Jong \& Westerhof, 2001; Fauth et al., 2014; Ferguson, 2012; Kunter \& Baumert, 2006), recent studies have shown that student perceptions of teaching quality can provide reliable and valid information 
both for research purposes and as feedback to teachers for formative evaluation of the quality of their teaching (Burniske \& Meibaum, 2012; Ferguson \& Danielson, 2014; Kane et al., 2013; Kyriakides, 2005; Peterson et al., 2000).

\section{Using Student Perceptions of Teaching for the Development of Teaching and Teachers-The Process Model of Student Feedback on Teaching (SFT)}

The basic idea of using student feedback for the development of teaching is to give teachers a comprehensive view of their teaching from the students' perspective, which might result in valuable information or data for teachers about the quality of their teaching. Based on the feedback, they can carry out improvement-oriented actions which might enhance their lessons. This, in turn, could result in more positive perceptions of the teaching by the students and improved learning processes for those students. The first experiments with this form of developing teaching were already being done in the USA in the 1920s (Remmers, 1927). Moreover, the underlying simplistic model of this approach is also commonly used in the data-based decision making research field (Lai et al., 2014; Poortman \& Schildkamp, 2016; Schildkamp, 2019; van Geel et al., 2016), where it is stated that the use of teaching-related data, such as the evaluations of students' learning processes, can help to improve teaching and students' learning outcomes. In addition, the process of obtaining feedback from students and the associated student-teacher communication is an educational process, which can promote skills such as giving and receiving feedback, discussability, dealing with criticism, and different points of view (e.g., Bastian, 2010; Zierer \& Wisniewski, 2019). Student feedback is still seen as a way of promoting student voice (Cook-Sather, 2002, 2007): the voice of students in their own education (Lincoln, 1995). It seems important for such a process to focus on the formative use of student ratings. A summative use of student ratings in schools for accountability purposes could hinder such effects as the teachers would need to justify their teaching. Notably, the use of student feedback for developmental purposes in schools seems to be almost exclusive to Western countries. A systematic literature review on this topic identified studies from Europe, the USA, Australia, and Turkey only, although validated student perception questionnaires for assessing teaching quality also exist for the Asian region, for example (see Chap. 9 of this volume).

Regarding the practical implementation of student feedback, it becomes apparent that the process of gathering and evaluating feedback is not quite that simple. For example, it is necessary both to overcome routines like basing decisions on intuition and instinct (Schildkamp \& Kuiper, 2010) and for teachers to be data literate in order to use data systematically for the improvement of their lessons (Kippers et al., 2018; Mandinach \& Gummer, 2016). Furthermore, the process of utilizing student perceptions of teaching quality as data to improve teaching is complex, as it is influenced by teacher, student, and class characteristics, and occurs within an organizational context 


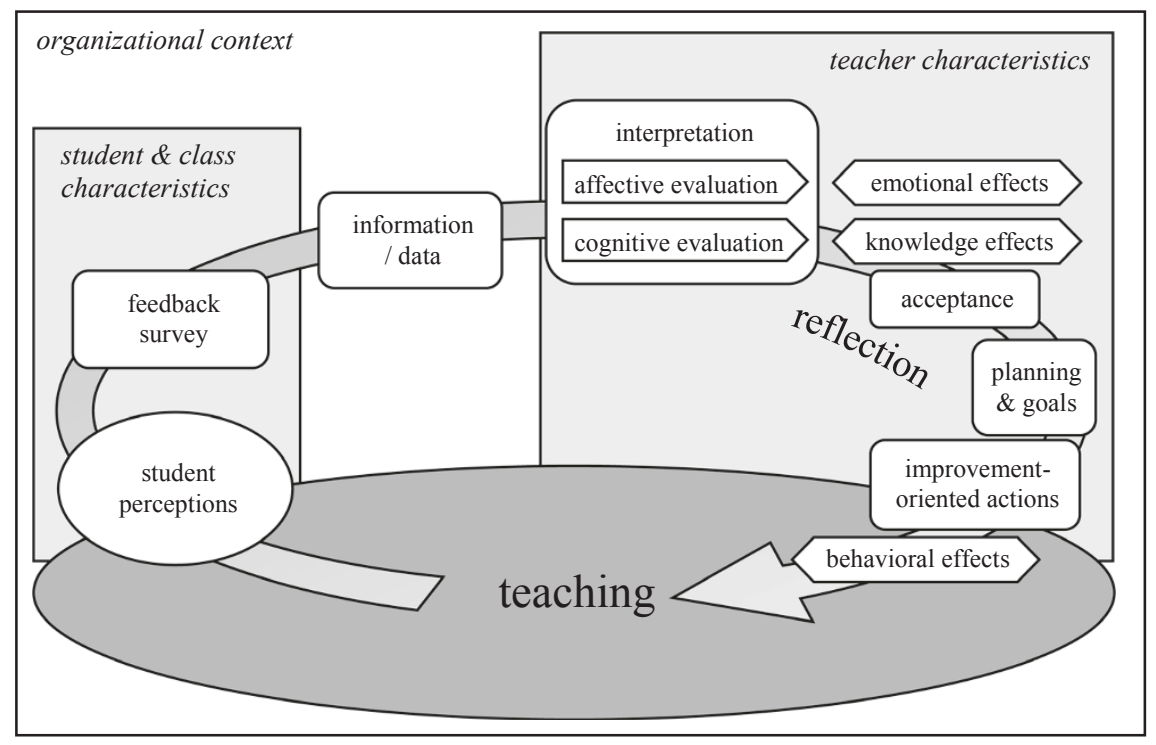

Fig. 1 Process model of student feedback on teaching (SFT, Source Own)

(Schildkamp, 2019). Moreover, the success of this process can depend on many situational factors, such as questionnaire characteristics, personal reactions evaluating the feedback, or the choice of improvement-oriented actions based on the feedback. In this introductory chapter, we therefore gradually suggest a more complex model of the use of student feedback for developing teaching and teachers which-among other things-includes these factors. The model is visualized in Fig. 1.

The process starts with the students, who perceive the teaching in class. These perceptions can be captured via a student feedback survey. For this purpose, questionnaires are often used, which include items to be rated or open-ended questions. Student perceptions as well as their teaching quality ratings might be influenced by student and class characteristics (Bijlsma et al., 2019; Fauth et al., 2020; Levy et al., 1992).

Once the feedback is collected (that is, when the information or data are available), it must be understood and interpreted by the teacher. Following this, a cognitive process takes place, which is often described as reflection in the context of teacher training and professional development (e.g., Beauchamp, 2006; Korthagen \& Wubbels, 1995). Reflection should lead to better understanding of one's own teaching, and subsequently to better teaching practice (Driessen et al., 2008; Ertmer \& Newby, 1996).

Research on feedback from organizational psychology could provide important insights with regard to the process of reflection on feedback. According to Ilgen et al. (1979), the processing of received performance feedback follows several steps. First, the feedback message is perceived by the person receiving the feedback, in which the accuracy and intensity of the perception play an important role. Then a decision 
is made about the extent to which the perceived feedback message is accepted, i.e., whether the received information is considered to be truthful. As a result, the desire or intention to respond to the feedback can arise, followed by the setting of goals in this regard (intended response) and the implementation of the intended response in practice (see also Kinicki et al., 2004).

A comparable process model is also found in Smither et al. (2005), with the authors proposing the following steps: initial reactions, goal-setting and related actions, taking action and subsequent performance improvement. As an extension of these sequence models, Kahmann and Mulder (2011) included not only cognitive reactions to feedback, but also affective reactions by the person receiving the feedback, which can both eventually result in behavioral effects.

For our theory of action, we combined these sequence models considering the context of teachers as recipients of student feedback. Therefore, we view the perception and interpretation of feedback not only from cognitive perspectives, but also from affective ones.

Regarding these emotional effects, student feedback can evoke positive emotions such as satisfaction and joy, or negative ones such as dissatisfaction or defensiveness. These are primarily influenced by the actual as well as the expected positivity or negativity of the feedback, respectively. Knowledge effects can occur when feedback provides the teacher with new information about the students' view of his or her teaching or the feedback reinforces the teacher's existing knowledge. Then, a comparison between one's own perceptions and standards for teaching takes place. Discrepancies, which emerge, must be accepted in order for the teacher to consider changes in their teaching. Feedback data, which differ strongly from one's own objectives and standards concerning the own teaching together with negative emotional reactions, can lead to rejection of the feedback (Kahmann \& Mulder, 2011; Kluger $\&$ DeNisi, 1996). Furthermore, it should be noted that a discrepancy between the actual state and the target state can also lead to abandonment or modification of the previously set objectives or standards in order to avoid or reduce any further effort (Kluger \& DeNisi, 1996).

After the perception and acceptance of a possible area of improvement, goals for the elimination of a discrepancy can be set, followed by planning for the implementation of the intended response (Smither et al., 2005). Subsequently, as behavioral effects, improvement-oriented actions can take place, such as adaptive teaching to the different needs of students in the class (Gaertner, 2014), increased attention to specific aspects during teaching (Röhl \& Rollett, 2021), discussions with students about the feedback for collaborative improvement (Gaertner, 2014), or participation in special training courses (Balch, 2012). If the actions have the desired effect on teaching practices, this might result in higher ratings from students in subsequent feedback surveys, and/or better learning outcomes.

We consider the presented process model to be a promising tool for structuring research and research questions on student feedback on teaching in schools. The model combines existing research from different research fields and covers what is known about developmental process of teaching and teachers based on student feedback. We acknowledge that the model is an ideal presentation; in real school 
settings, influencing factors like the student, class, teacher, and organizational aspects need to be considered. Therefore, the present volume covers a variety of topics linked to these influencing factors. Subsequently, we use this model to arrange and link the contributions and perspectives of this volume in their meaning and connection to this process.

\section{Overview of the Volume}

In Part One of the volume, student perceptions of teaching quality and their validity and reliability are discussed by considering several theoretical and psychometric issues. These topics address issues which concern theoretical and research questions pertaining the beginning of the cycle of the Process Model of Student Feedback on Teaching (SFT) just introduced. In Chap. 2, Bijlsma et al. introduce the measurement of student perceptions from three psychometric perspectives which dominate contemporary research on teaching quality. They aim to connect psychometric theories and the different perspectives on what (measured) student perceptions are seen to be, as well as the different perspectives regarding how and for what purposes student perceptions should be used. In Chap. 3, Röhl and Rollett —in line with the Process Model of Student Feedback on Teaching (SFT) - discuss theoretically assumed teaching quality dimensions, which can be distinguished in student feedback surveys. Findings on the importance of teachers' communion with students (warmth or cooperation) as a potentially biasing factor in student ratings of instructional quality are also discussed. For Chap. 4, Bijlsma conducted a systematic review on the psychometric quality of student perception questionnaires (SPQ). She presents detailed overviews with general information about the SPQs, the results of the evaluation, and the constructs measured by the SPQs. In Chap. 5, van der Lans focuses on evidence showing that student questionnaires and classroom observation instruments can provide reliable feedback to teachers. He provides empirical evidence indicating that feedback of classroom observations and student questionnaires can be calibrated on the same continuum of instructional effectiveness; he moves on to discuss implications for theory, future research, and practice. In Chap. 6, Schweig and Martínez present an overview of literature from different fields which examines consensus in different measures of teaching quality. They consider these alongside key assumptions and consequences of those measurement models and analytic methods which are commonly used to summarize student survey reports of teaching quality. In Chap. 7, Göllner et al. continue with further findings on the particularities of student ratings of instructional quality, pointing out the importance of considering how exactly the referent and the addressee are noted in survey items and presenting related perspectives for future in-depth research approaches.

Part Two of the book focuses on the use of student feedback for the development of teaching and teachers. Following the SFT model, we arrive here at interpretation, reflection, and the teacher improvement elements. In Chap. 8, Wisniewski and Zierer start with an overview of functions of and success conditions for student feedback 
in the development of teaching and teachers. They point out why feedback is important for the professional development of teachers in general, and discuss three basic functions of student feedback in schools. This is followed, in Chap. 9, by Röhl's contribution, in which the first meta-analysis of the effects of student feedback on teaching quality in secondary schools is presented, providing insights on its effectiveness and potential moderating variables. In Chap. 10, Röhl and Gärtner systematize relevant factors influencing the utilization of student feedback by teachers into three domains: personal characteristics of feedback recipients (teachers), characteristics of the organization (school), and characteristics of feedback information (data). The two chapters which follow discuss student feedback from a more practical point of view. Göbel et al. (Chap. 11) focus on the use of student feedback to improve teaching quality during practical phases in teacher education. The authors discuss challenges and opportunities for the use of student feedback as an instrument for reflection on teaching and professional development for pre-service teachers. Schmidt and Gawrillow (Chap. 12) describe the theoretical parameters of reciprocal student-teacher feedback on cooperation between students and teachers, and outline results of an empirical study on the effects of the reciprocal method on the perceived quality of cooperation and on teacher health.

In the next part, three chapters of the volume provide supplementary perspectives on the use of student feedback for developing teaching and teachers, relating to the final part of the feedback cycle of the SFT model. Jones and Hall shed light on the critical pragmatism perspective (Chap. 13), and focus on how student feedback can facilitate dialogue and thus contribute to the development of schools as democratic communities. The multisource feedback perspective in organizations, and the transferability of this perspective to student-to-teacher feedback in schools is discussed by Fleenor (Chap. 14). In Chap. 15, Uttl overviews the lessons to be learned from research on student evaluation of teaching in higher education providing insights to be taken up in research on student feedback on teaching in schools.

Finally, in the concluding chapter of the book, Rollett et al. summarize the findings and conclusions drawn from the chapters in this volume and discuss the directions forward for researchers, policy makers, and schools.

Acknowledgments The editors would like to thank the Dutch Research Council (NWO; project number 36.201.009) and the University of Education Freiburg (Germany) for funding the open access publication of this volume.

\section{References}

Balch, R. T. (2012). The validation of a student survey on teacher practice. Doctoral dissertation, Vanderbilt University, Nashville, TN.

Bastian, J. (2010). Feedbackarbeit in Lehr-Lern-Prozessen [Working with feedback in teachinglearning processes]. Gruppendynamik und Organisationsberatung, 41, 21-37. https://doi.org/10. 1007/s11612-010-0097-4. 
Beauchamp, C. (2006). Understanding reflection in teaching: A framework for analyzing the literature. Doctoral dissertation, McGill University, Montreal. https://escholarship.mcgill.ca/concern/ theses/w0892g316.

Bijlsma, H. J.E., Glas, C. A. W., \& Visscher, A. J. (2019, August 12). The factors influencing digitally measured student perceptions of teaching quality. Paper presented at the EARLI conference in Aachen.

Burniske, J., \& Meibaum, D. (2012). The use of student perception data as a measure of teaching effectiveness. Texas Comprehensive Center. Retrieved from http://txcc.sedl.org/resources/briefs/ number_8/index.php.

Cook-Sather, A. (2002). Authorizing students' perspectives: Toward trust, dialogue, and change in education. Educational Researcher, 31(4), 3-14.

Cook-Sather, A. (2007). What would happen if we treated students as those with opinions that matter? The benefits to principals and teachers of supporting youth engagement in school. NASSP Bulletin, 91(4), 343-362.

Darling-Hammond, L. (2013). Getting teacher evaluation right: What really matters for effectiveness and improvement. Teachers College. https://doi.org/10.1177/0192636507309872.

de Jong, R., \& Westerhof, K. J. (2001). The quality of student ratings of teacher behaviour. Learning Environments Research, 4, 51-85. https://doi.org/10.1023/A:1011402608575.

Driessen, E., van Tartwijk, J., \& Dornan, T. (2008). The self-critical doctor: Helping students become more reflective. BMJ, 336, 827-830. https://doi.org/10.1136/bmj.39503.608032.AD.

Ertmer, P. A., \& Newby, T. J. (1996). The expert learner: Strategic, self-regulated and reflective. Instructional Sciences, 24, 1-24.

Fauth, B., Decristan, J., Rieser, S., Klieme, E., \& Büttner, G. (2014). Student ratings of teaching quality in primary school: Dimensions and prediction of student outcomes. Learning and Instruction, 29, 1-9.

Fauth, B., Wagner, W., Bertram, C., Göllner, R., Roloff-Bruchmann, J., Lüdtke, O., et al. (2020). Don't blame the teacher? The need to account for classroom characteristics in evaluations of teaching quality. Journal of Educational Psychology, 112, 1284-1302. https://doi.org/10.1037/ edu0000416.

Ferguson, R. F. (2012). Can student surveys measure teaching quality? Phi Delta Kappan, 94(3), 24-28. https://doi.org/10.1177/003172171209400306.

Ferguson, R. F., \& Danielson, C. (2014). How framework for teaching and tripod 7Cs evidence distinguish key components of effective teaching. In T. J. Kane, K. A. Kerr, \& R. C. Pianta (Eds.), Designing teacher evaluation systems (pp. 98-144). Jossey-Bass.

Frase, L. E., \& Streshly, W. (1994). Lack of accuracy, feedback, and commitment in teacher evaluation. Journal of Personnel Evaluation in Education, 8(1), 47-57. https://doi.org/10.1007/BF0 0972709.

Gaertner, H. (2014). Effects of student feedback as a method of self-evaluating the quality of teaching. Studies in Educational Evaluation, 42, 91-99. https://doi.org/10.1016/j.stueduc.2014. 04.003 .

Garet, M. S., Wayne, A. J., Brown, S., Rickles, J., Song, M., Manzeske, D., et al. (2017). The impact of providing performance feedback to teachers and principals: Executive summary. National Center for Education Evaluation and Regional Assistance, Institute of Education Sciences, U.S. Department of Education.

Haertel, B. E. H. (2013). Reliability and validity of inferences about teachers based on student test scores. William H. Angoff memorial lecture series. Educational Testing Service.

Hattie, J. (2009). Visible learning: A synthesis of over 800 meta-analyses relating to achievement. Routledge. https://doi.org/10.1007/s11159-011-9198-8.

Hattie, J., \& Timperley, H. (2007). The power of feedback. Review of Educational Research, 77, 81-112. https://doi.org/10.3102/003465430298487.

Ilgen, D. R., Fisher, C. D., \& Taylor, S. M. (1979). Consequences of individual feedback on behavior in organizations. Journal of Applied Psychology, 64(4), 349-371. https://doi.org/10.1037/00219010.64.4.349. 
Kahmann, K., \& Mulder, R. H. (2011). Feedback in organizations: A review of feedback literature and a framework for future research. Regensburg. https://www.uni-regensburg.de/psycho logie-paedagogik-sport/paedagogik-2/medien/kahmann_mulder_2011.pdf. Accessed 31 October 2019.

Kane, T. J., McCaffrey, D. F., Miller, T., \& Staiger, D. O. (2013). Have we identified effective teachers? Bill \& Melinda Gates Foundation. http://www.metproject.org/downloads/MET_Val idating_Using_Random_Assignment_Research_Paper.pdf. Accessed 29 August 2020.

Kane, T. J., \& Staiger, D. O. (2012). Gathering feedback for teaching: Combining high-quality observations with student surveys and achievement gains. Bell \& Melinda Gates Foundation.

Kinicki, A. J., Prussia, G. E., Wu, B., \& McKee-Ryan, F. M. (2004). A covariance structure analysis of employees' response to performance feedback. The Journal of Applied Psychology, 89, 10571069. https://doi.org/10.1037/0021-9010.89.6.1057.

Kippers, W. B., Poortman, C. L., Schildkamp, K., \& Visscher, A. J. (2018). Data literacy: What do educators learn and struggle with during a data use intervention? Studies in Educational Evaluation, 56, 21-31. https://doi.org/10.1016/j.stueduc.2017.11.001.

Kluger, A. N., \& DeNisi, A. (1996). The effects of feedback interventions on performance: A historical review, a meta-analysis, and a preliminary feedback intervention theory. Psychological Bulletin, 119(2), 254-284. https://doi.org/10.1037/0033-2909.119.2.254.

Korthagen, F. A. J., \& Wubbels, T. (1995). Characteristics of reflective practitioners: Towards an operationalization of the concept of reflection. Teachers and Teaching, 1, 51-72. https://doi.org/ 10.1080/1354060950010105.

Kruger, J., \& Dunning, D. (1999). Unskilled and unaware of it: How difficulties in recognizing one's own incompetence lead to inflated self-assessments. Journal of Personality and Social Psychology, 77(6), 1121-1134. https://doi.org/10.1037/0022-3514.77.6.1121.

Kunter, M., \& Baumert, J. (2006). Who's the expert? Construct and criteria validity of student and teacher ratings of instruction. Learning Environment Research, 9, 231-251. https://doi.org/10. 1007/s10984-006-9015-7.

Kyriakides, L. (2005). Drawing from teacher effectiveness research and research into teacher interpersonal behaviour to establish a teacher evaluation system: A study on the use of student ratings to evaluate teacher behaviour. Journal of Classroom Interaction, 40(2), 44-66.

Lai, M. K., Wilson, A., McNaughton, S., \& Hsiao, S. (2014). Improving achievement in secondary schools: Impact of a literacy project on reading comprehension and secondary school qualifications. Reading Research Quarterly, 49(3), 305-334. https://doi.org/10.1002/rrq.73.

Levy, J., Wubbels, T., \& Brekelmans, M. (1992). Student and teacher characteristics and perceptions of teacher communication style. Journal of Classroom Interaction, 27, 23-29.

Lincoln, Y. S. (1995). In search of student voices. Theory into Practice, 34, 88-93.

Mandinach, E. B., \& Gummer, E. S. (2016). What does it mean for teachers to be data literate: Laying out the skills, knowledge, and dispositions. Teaching and Teacher Education, 60, 366-376. https:// doi.org/10.1016/j.tate.2016.07.011.

Muijs, D. (2006). Measuring teacher effectiveness: Some methodological reflections. Educational Research and Evaluation, 12(1), 53-75. https://doi.org/10.1080/13803610500392236.

Nye, B., Konstantopoulos, S., \& Hedges, L. V. (2004). How large are teacher effects? Educational Evaluation and Policy Analysis, 26(3), 237-257. https://doi.org/10.3102/01623737026003237.

Peterson, K. D., Wahlquist, C., \& Bone, K. (2000). Student surveys for school teacher evaluation. Journal of Personnel Evaluation in Education, 14, 135-153. https://doi.org/10.1023/A:100810 2519702.

Poortman, C. L., \& Schildkamp, K. (2016). Solving student achievement problems with a data use intervention for teachers. Teaching and Teacher Education, 60, 425-433. https://doi.org/10.1016/ j.tate.2016.06.010.

Praetorius, A.-K., Pauli, C., Reusser, K., Rakoczy, K., \& Klieme, E. (2014). One lesson is all you need? Stability of instructional quality across lessons. Learning and Instruction, 31, 2-12. https:// doi.org/10.1016/j.learninstruc.2013.12.002.

Quaglia, R., \& Corso, M. (2014). Student voice. The instrument of change. Corwin Press. 
Remmers, H. H. (1927). The purdue rating scale for instructors. Educational Administration and Supervision (6), 399-406.

Röhl, S., \& Rollett, W. (2021). Jenseits von Unterrichtsentwicklung: Intendierte und nichtintendierte Nutzungsformen von Schülerfeedback durch Lehrpersonen [Beyond teaching development: Intended and non-intended ways of utilization of student feedback by teachers]. In K. Göbel, C. Wyss, K. Neuber, \& M. Raaflaub (Eds.), Quo vadis Forschung zu Schülerrückmeldungen? [Quo vadis research on student feedback?]. Springer VS. https://doi.org/10.1007/9783-658-32694-4.

Schildkamp, K. (2019). Data-based decision-making for school improvement: Research insights and gaps. Educational Research, 1-17. https://doi.org/10.1080/00131881.2019.1625716.

Schildkamp, K., \& Kuiper, W. (2010). Data-informed curriculum reform: Which data, what purposes, and promoting and hindering factors. Teaching and Teacher Education, 26(3), 482-496. https://doi.org/10.1016/j.tate.2009.06.007.

Smither, J. W., London, M., \& Reilly, R. R. (2005). Does performance improve following multisource feedback? A theoretical model, meta-analysis, and review of empirical findings. Personnel Psychology, 58, 33-66. https://doi.org/10.1111/j.1744-6570.2005.514_1.x.

van Geel, M., Keuning, T., Visscher, A. J., \& Fox, J. P. (2016). Assessing the effects of a schoolwide data-based decision-making intervention on student achievement growth in primary schools. American Educational Research Journal, 53(2), 360-394. https://doi.org/10.3102/000283121663 7346.

Visscher, A. J. (2017). Gericht ontwikkelen van leerkrachtkwaliteiten [Developing teacher qualities in a targeted way]. University of Twente.

Voerman, L., Meijer, P. C., Korthagen, F. A. J., \& Simons, R. J. (2012). Types and frequencies of feedback interventions in classroom interaction in secondary education. Teaching and Teacher Education, 28(8), 1107-1115. https://doi.org/10.1016/j.tate.2012.06.006.

Zierer, K., \& Wisniewski, B. (2019). Using student feedback for successful teaching. Routledge.

Sebastian Röhl has been an Academic Assistant in the Department of Educational Science at the University of Education Freiburg and is currently a Postdoctoral Researcher in the Institute of Education at Tübingen University (Germany). Before that he worked for more than 10 years as a grammar school teacher, school development consultant, and in teacher training. Among other areas, he conducts research in the fields of teaching development and teacher professionalization through feedback, social networks in inclusive school classes, as well as teachers' religiosity and its impact on professionalism. In addition, he is the Director of an in-service professional master's study program for teaching and school development.

Hannah Bijlsma is a researcher (Ph.D.) at the section of Teacher Professionalization at the University of Twente (the Netherlands) and a primary school teacher (grade 1). Her research focuses on measuring teaching quality and on the use of student perceptions of teaching quality in school contexts. In 2016 she founded a professional association for academic primary school teachers, of which she has been chairman for about five years. She is now a board member of the International Congress for School Effectiveness and Improvement (ICSEI) and a board member of the EARLI SIG on School Effectiveness and Improvement.

Wolfram Rollett is a Professor of Empirical Educational Research at the University of Education Freiburg and the Freiburg Advanced Center of Education (FACE). Previously he worked as a researcher and lecturer in the field of Educational Science and Psychology at the Universities of Potsdam, Braunschweig, Dortmund, and Wuppertal. His research focuses on school development processes, the quality of extra- and co-curricular activities, educational effectiveness, and classroom composition. 
Open Access This chapter is licensed under the terms of the Creative Commons Attribution 4.0 International License (http://creativecommons.org/licenses/by/4.0/), which permits use, sharing, adaptation, distribution and reproduction in any medium or format, as long as you give appropriate credit to the original author(s) and the source, provide a link to the Creative Commons license and indicate if changes were made.

The images or other third party material in this chapter are included in the Chapter's Creative Commons license, unless indicated otherwise in a credit line to the material. If material is not included in the Chapter's Creative Commons license and your intended use is not permitted by statutory regulation or exceeds the permitted use, you will need to obtain permission directly from the copyright holder.

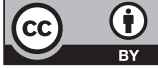

